\title{
Longitudinal trends and interelations of mitochondrial function in adults and pediatric critically ill patients
}

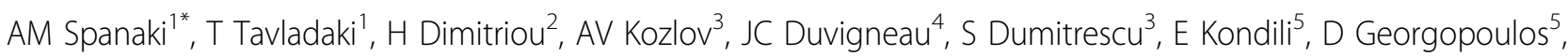 \\ G Briassoulis ${ }^{1}$
}

From ESICM LIVES 2015

Berlin, Germany. 3-7 October 2015

\section{Introduction}

Bioenergetic failure due to mitochondrial dysfunction has been implicated as an important pathophysiological mechanism underlying poor outcome in critical illness.

\section{Objectives}

We examined the longitudinal changes of ATP, $\mathrm{NO2}^{-}$ and $\mathrm{N}^{-}{ }^{-}$in patients with severe sepsis (SS) or traumarelated systemic inflammatory response syndrome (SIRS) compared to healthy-controls $(\mathrm{H})$ and their relations to intracellular heat shock proteins (HSP)-72 and $-90 \alpha$, metabolism and outcome.

\section{Methods}

Seventy-eight adults (SS/22; non-infectious SIRS /23; healthy $(\mathrm{H}) / 33$ ) and sixty-two children (SS/15; noninfectious SIRS /20; healthy $(\mathrm{H}) / 27$ ) were studied. Blood samples obtained on days 1, 3 and 5. Energy expenditure (EE) of patients was measured with the Gas Module E-COVX. HSPs expressions in monocytes $(\mathrm{m})$ or neutrophils (n) were determined using flow cytometry. ATP concentrations were measured by the luciferase luminescent assay. $\mathrm{NO2}^{-}$and $\mathrm{NO3}^{-}$determination was performed using the Sievers Nitric Oxide Analyzer.

\section{Results}

In both, adults and children, mitochondrial bioenergetics showed different longitudinal trends for survivors and non-survivors. The nitrite/nitrate ratio increased longitudinally in critical illness $(\mathrm{p}<0.05)$. Among adult survivors, N03 $^{-}(26422 \pm 19368$ vs. $13807 \pm 3740 \mathrm{nM}, \mathrm{p}<0.04)$ and
ATP concentrations $(503 \pm 645$ vs. $185 \pm 192 \mathrm{nM})$ decreased from day 1 to 3 , and lactate from days 1 to 3 to 5 ( $15 \pm 11$ vs. $10 \pm 4$ vs. $8 \pm 5 \mathrm{mMol} / \mathrm{L}, \mathrm{p}<0.001)$. Survivors had higher ATP, $\mathrm{N}^{-}(\mathrm{p}<0.04)$, N02- $(\mathrm{p}<0.04)$, V02 ( $<<0.0001), \mathrm{VC0} 2(\mathrm{p}<0.0001), \mathrm{EE}(\mathrm{p}<0.04)$ on day $1, \mathrm{~N}^{-}(\mathrm{p}<0.05)$ on day 3 , and lower lactate levels on days 1 and 5 ( $\mathrm{p}<0.03$ ), compared to non-survivors. Nonsurvived children had lower SID ( $28 \pm 5$ vs. $34 \pm 4$, p < $0.03)$ and mHSP72 (16 \pm 13 vs. $23 \pm 15$ MFI, p < 0.05) on days 1,5 .

\section{Conclusions}

Our data implicate bioenergetic failure and a drop in NO synthesis in white blood cells as possible pathophysiological mechanisms contributing to mortality. Our data suggest that in critically ill patients NO metabolism is linked to HSP72 and has a protective impact on mitochondrial function.

\section{Grant Acknowledgment}

This research has been co-financed by the European Union (European Social Fund (ESF)) and Greek national funds through the Operational Program "Education and Lifelong Learning" of the National Strategic Reference Framework (NSRF)-Research Funding Program: THALES.

\footnotetext{
Authors' details

${ }^{1}$ University of Crete/University Hospital, PICU, Heraklion, Greece. ${ }^{2}$ University of Crete, Medical School, Paediatric Haematology Oncology, Heraklion, Greece. ${ }^{3}$ Ludwig Boltzmann Institute for Experimental and Clinical Traumatology in the AUVA, Vienna, Austria. ${ }^{4}$ University of Veterinary Medicine, Vienna, Austria. ${ }^{5}$ University of Crete/University Hospital, ICU, Heraklion, Greece.
} 


\section{References}

1. Kozlov, et al: Annals of Intensive Care 2011, 1:41.

2. Lancet 2002, 360:219-23.

doi:10.1186/2197-425X-3-S1-A287

Cite this article as: Spanaki et al:: Longitudinal trends and interelations

of mitochondrial function in adults and pediatric critically ill patients.

Intensive Care Medicine Experimental 2015 3(Suppl 1):A287.

\section{Submit your manuscript to a SpringerOpen ${ }^{\circ}$ journal and benefit from:}

- Convenient online submission

- Rigorous peer review

- Immediate publication on acceptance

- Open access: articles freely available online

- High visibility within the field

- Retaining the copyright to your article

Submit your next manuscript at $>$ springeropen.com 